\title{
Contrasting patterns of litterfall seasonality and seasonal changes in litter decomposability in a tropical rainforest region
}

\author{
S. A. Parsons ${ }^{1}$, V. Valdez-Ramirez ${ }^{1}$, R. A. Congdon ${ }^{2}$, and S. E. Williams ${ }^{1}$ \\ ${ }^{1}$ Centre for Tropical Biodiversity and Climate Change, School of Marine and Tropical Biology, James Cook University, \\ Townsville, 4811, Australia \\ ${ }^{2}$ School of Marine and Tropical Biology, James Cook University, Townsville, 4811, Australia
}

Correspondence to: S. A. Parsons (scottanthonyparsons@gmail.com)

Received: 31 March 2014 - Published in Biogeosciences Discuss.: 3 June 2014

Revised: 31 July 2014 - Accepted: 22 August 2014 - Published: 18 September 2014

\begin{abstract}
The seasonality of litter inputs in forests has important implications for understanding ecosystem processes and biogeochemical cycles. We quantified the drivers of seasonality in litterfall and leaf decomposability using plots throughout the Australian wet tropical region. Litter fell mostly in the summer (wet, warm) months in the region, but other peaks occurred throughout the year. Litterfall seasonality was modelled well with the level of deciduousness of the site (plots with more deciduous species had lower seasonality than evergreen plots), temperature (higher seasonality in the uplands), disturbance (lower seasonality with more early secondary species) and soil fertility (higher seasonality with higher N:P/P limitation) (SL total litterfall model $1=$ deciduousness + soil $\mathrm{N}: \mathrm{P}+$ early secondary $\mathrm{sp} .: r^{2}=0.63, n=30 ;$ model $2=$ temperature + early secondary $\mathrm{sp} .+$ soil $\mathrm{N}: \mathrm{P}: r^{2}=$ $0.54, n=30 ;$ SL leaf $=$ temperature + early secondary sp. + rainfall seasonality: $r^{2}=0.39, n=30$ ). Leaf litter decomposability was lower in the dry season than in the wet season, driven by higher phenolic concentrations in the dry, with the difference exacerbated particularly by lower dry season moisture. Our results are contrary to the global trend for tropical rainforests; in that seasonality of litterfall input was generally higher in wetter, cooler, evergreen forests, compared to generally drier, warmer, semi-deciduous sites that had more uniform monthly inputs. We consider this due to more diverse litter shedding patterns in semi-deciduous and raingreen rainforest sites, and an important consideration for ecosystem modellers. Seasonal changes in litter quality are likely to have impacts on decomposition and biogeochemi-
\end{abstract}

cal cycles in these forests due to the litter that falls in the dry season being more recalcitrant to decay.

\section{Introduction}

Litterfall is an important component of forest function, and is inherently linked to net primarily productivity (NPP) and global biogeochemical cycles (Clark et al., 2001a; Aragão et al., 2009). Litter cycles are central in the exchange of carbon from terrestrial ecosystems to the atmosphere, and the tropical forest biome forms a major contribution to seasonal variations in the terrestrial carbon cycle (Bousquet et al., 2000; De Weirdt et al., 2012). The mechanisms determining litterfall seasonality remain poorly understood (Restrepo-Coupe et al., 2013). Moreover, understanding of the seasonality of litter inputs in forested ecosystems is a limiting factor in ecosystem models, especially for tropical forests (De Weirdt et al., 2012), which represent a large portion of global litter inputs and NPP (Clark et al., 2001b). Coupled with this, the chemical quality and decomposability of the material that falls at certain times of the year is an important regulator of biogeochemical cycles (Fierer et al., 2005; Cornwell et al., 2008). Understanding of how litter quality varies within years and between environments is thus essential in comprehending plant phenology, responses to the environment, and the effects on ecosystems and global cycles.

Litterfall comparisons over multiple locations are required to make inferences about patterns in litter seasonality (De Weirdt et al., 2012). Recent reviews of tropical forests have shown that increased rainfall seasonality generally causes 
more seasonal litter inputs (Chave et al., 2010; Zhang et al., 2014). These meta-analyses provide important insights to general trends; however there is potential therein to conceal finer scale drivers of variability. This is especially true in understanding phenology and litter patterns in tropical forests, due to high species richness and diversity in plant phenological characteristics (Townsend et al., 2008). For instance, deciduous species in seasonally wet tropical forests can shed litter as a response to new growth (e.g. in wetter or warmer months), or as a response to dry seasons and cooler/lowgrowth periods (Hyland et al., 2002).

Here we aimed to determine the drivers of seasonality in litterfall in a tropical rainforest region. We use data from the study of Parsons et al. (2014), who quantified spatial variability in litterfall rates, litter quality and leaf decomposability. We extend this work to understand the temporal distribution of litterfall and litter decomposability in order to better comprehend the variability in ecosystem processes in the region. We ask, what determines regional variability in the extent of seasonality in litterfall inputs in a diverse tropical region of different rainforest types (e.g. rainfall patterns, temperature, soil fertility, community composition)? Does the chemistry of litter inputs change seasonally (i.e. between wet and dry seasons), with determinable effects on ecosystem processes such as decomposition? We anticipate that, in line with recent reviews, rainfall seasonality will play a significant part in determining the extent of seasonality of litterfall, because the region of focus here contains variation in the extent of the dry season (i.e. marked dry season and summer monsoon). However, the extent that other fine-scale factors, for instance the prevalence of deciduousness (Webb, 1968) and disturbance (Parsons et al., 2014), contribute to variability in litterfall seasonality remains largely unknown. Also, our knowledge of seasonal changes in litter chemical composition and decomposability is limited; however, any inferences should rely on both climatic (e.g. wind effects on green leaf fall; climate and soil fertility impacts on litter chemistry in the short term) and biotic (species/community) physiological responses to the changing seasons.

\section{Methods}

\subsection{Study sites and litterfall quantification}

The data for litterfall and decomposability used here are the same as determined in Parsons et al. (2014). Seasonality calculations were determined for litterfall collected at approximately monthly intervals over 2 years, in tropical rainforest throughout the wet tropical region of north Queensland, Australia. Plots were located between $\sim 16$ and $19^{\circ} \mathrm{S}$, incorporating an elevational sampling design on four mountain ranges (Atherton, Carbine, Spec and Windsor Uplands; see Supplement Table S1 for locations). In Parsons et al. (2014), 40 plots distributed over 20 sites (two plots per site separated by $\sim 400 \mathrm{~m}$ ) were used; however, 8 of these plots (all in the Atherton Uplands) suffered significant cyclone damage prior to the study and litterfall rates were heavily disturbed. Here we use the 32 non-damaged plots to make inferences about seasonality. We used data from five litter traps of $0.25 \mathrm{~m}^{2}$ at each plot. We focus here on total litterfall (leaves, woody material $<2 \mathrm{~cm}$ diameter, flowers, fruits and very fine unclassified), leaf litterfall, leaf litter chemistry and in situ decomposability (see following).

Elevation of the plots ranged from near sea level to $\sim 1300 \mathrm{~m}$ (mean annual temperature range $17.4-23.9^{\circ} \mathrm{C}$, mean annual precipitation range $1400-3380 \mathrm{~mm}$, Table S1 in Supplement). Seasonality in rainfall is spatially varied, although generally high in the region, with most rainfall occurring in the summer months, December-March (Parsons, 2011). Soil types are described in Parsons et al. (2014) and are shown in Supplement Table S1. Soil fertility was generally poor to extremely poor due to old geology, especially for phosphorus contents, although some sites in the Atherton region had relatively higher fertility (newer volcanics) (Parsons, 2011; Parsons et al., 2012, 2014). While rainfall and moisture may increase in cooler upland rainforests, in our data set temperature and rainfall seasonality were not crosscorrelated (i.e. rainfall does not change significantly from the uplands to the lowlands, aided by the inclusion of multiple sub-regions with differing rainfall patterns). However, our study did not include the wettest mountaintops in north Queensland ( $>1400 \mathrm{~m}$ elevation), which have more aseasonal rainfall than most of our plots (Parsons, 2011; Parsons et al., 2014).

\subsection{Litter quality and decomposability}

To understand the seasonality of litter chemical inputs and the effects on decomposition, we used leaf litter chemical and in situ leaf decomposability data as in Parsons et al. (2011, 2012, 2014). The decomposability value is an estimate of the in situ decomposability of leaf litter based on the chemical make up of the leaves and the characteristics of the plot, determined with near-infrared spectrometry (Parsons et al., $2011,2012,2014)$. This is shown as the predicted decay rate from the commonly used single exponential decay equation (Wieder and Lang, 1982), represented as rate per year. To determine whether decomposability was different in the wet season (31 October-1 April) compared to the dry season (remainder of the year), we made comparisons between mean values for each season within plots with two-way ANOVA. For this, we used leaf decomposability, along with the litter chemical compositions: total $\mathrm{N}$, total $\mathrm{P}$, total $\mathrm{Ca}$, total $\mathrm{C}$, lignin, $\alpha$-cellulose and total phenolics/tannins, with season and plot as factors. This data set is also from Parsons et al. $(2011,2014)$. 


\subsection{Seasonality calculations}

Seasonality indexes were calculated for each plot using vector/circular algebra for total litterfall, leaf litterfall and leaf decomposability (Zimmerman et al., 2007; Chave et al., 2010). We employed this method because linear or Julian timescales fail in seasonality measurements when the process being studied occurs year-round. For example, if peaks or troughs in litterfall occur primarily between December and January, the linear mean would incorrectly fall in June. While other methods exist to define seasonality (e.g. Zhang et al. 2014), this method is potentially the most accurate measure (Jammalamadaka and Sengupta, 2001). For this calculation we used the average value from the collection month (defined as the mid-point between trap reset dates), with the month converted to a number (i.e. angle) between 0 (1 January) and 330 (1 December). This allows the data to be presented in a polar plot (month/days = degrees). The length of the vectors for each month is the mean value for that month from the 2 years (i), $L_{\text {mon }}\left(\mathrm{tha}^{-1} \mathrm{yr}^{-1}\right.$ for litterfall values, and predicted exponential decay value for leaf decomposability). The analyses produced a value for the mean vector, i.e. date, $m=\left(m_{x}, m_{y}\right)$, and the index of seasonality (SL, for use here: $\mathrm{SL}_{\text {tot }}=$ total litterfall seasonality; $\mathrm{SL}_{\text {leaf }}=$ leaf litterfall seasonality; $\mathrm{SL}_{\text {decomp }}=$ decomposability seasonality). The vector $(m)$ was determined from the monthly values ( $\left.L_{\text {mon }}\right)$ using the equation

$m_{x}=\frac{1}{12} \sum L_{\mathrm{mon}} \cos (30 \times i)$;

$m_{y}=\frac{1}{12} \sum L_{\text {mon }} \sin (30 \times i)$

and the seasonality index as

$\mathrm{SL}=\frac{\|m\|}{L}$,

where $L$ is the annual litterfall/mean decomposability value, i.e. sum of $L_{\text {mon }}$ for the plot. The SL values measured the extent that litter values were distributed throughout the year on a scale 0 to 1 (e.g. $0 \approx$ evenly distributed, $1 \approx$ all litter fell in 1 month) (Jammalamadaka and Sengupta, 2001; Zimmerman et al., 2007; Chave et al., 2010).

\subsection{Drivers of seasonality}

Seasonality was compared between vegetation structural types using the classification of Webb (1968). This defines the level of deciduousness, in our case relating to three classes, including one evergreen and two raingreen classifications: "evergreen", where healthy plants are never entirely leafless - including microphyll fern forests, Acacia closed forests or notophyll vine forests with Acacia sp. canopies $(n=10$, Table S1 in Supplement); "quasi-evergreen", with only a few scattered deciduous emergent species $(n=10)$; and semi-deciduous, where there is a higher proportion of obligate deciduous species than the other classifications $(n=$ 12) (Webb, 1968). These classifications were scaled $1-3$ in order of deciduousness for analyses below.

To determine the drivers of patterns in seasonality, we used correlation analysis and best-subset linear regressions on the SL values. Environmental input data for this are the same as in Parsons et al. (2014): mean annual temperature (MAT), mean annual precipitation (MAP), mean annual radiation (MAR), rainfall seasonality, moisture seasonality (mean dry season leaf wetness value from on-site sensors), soil total $\mathrm{N}$, total $P$, total $\mathrm{Ca}$, total organic $\mathrm{C}$, total $\mathrm{Na}$, and $\mathrm{N}: \mathrm{P}$ (see Supplement Table $\mathrm{S} 1$ for all raw input data). Also, community composition was included as deciduousness, plant species richness and plant density as estimated on transects through the litter traps, as in Parsons et al. (2014). Disturbance has been shown to be a factor in determining spatial variability in litterfall rates at these plots (Parsons et al., 2014). We therefore included the proportion of disturbance species, i.e. listed as components of rainforest regrowth or early secondary species (here termed "early secondary species") in Hyland et al. (2002), as in Parsons et al. (2014), in model building. Any models that included these community data contained 30 of the 32 plots due to missing data (Supplement Table S1). We also included total litterfall rate and leaf decomposability (mean value per plot) in this analysis. Preliminary analyses showed that soil N:P increased in the data set with increased rainfall seasonality (Pearson correlation $=0.496, P=0.004)$. This was not an artefact of our wet sites being on richer soils, as other studies in the region have noted (Parsons, 2011), because the majority of sites with this pattern were removed due to cyclone damage (Parsons et al., 2014). It was more likely due to greater prevalence of $\mathrm{N}$ fixating species, leading to higher soil $\mathrm{N}$, in the more seasonal sites (Parsons, 2011). This phenomenon is considered in analyses.

If a wet-dry seasonal difference in litter decomposability was present, we were also interested in what determined the extent of this difference among plots (i.e. using the environmental and community data from above). To understand this, we used best-subset regression with environmental variables, in this case run on the difference between the dry and wet season mean decomposability for each plot:

i.e. decomposability seasonal difference

$=\frac{\mu_{\mathrm{dry}}-\mu_{\mathrm{wet}}}{\mu_{\mathrm{wd}}}(\%)$,

where $\mu_{\mathrm{dry}}$ is the dry season mean for the plot $\mu_{\text {wet }}$ is the wet season mean and $\mu_{\mathrm{wd}}$ is the annual mean for the plot. 
Table 1. Descriptive statistics of litterfall seasonality indices (annual distribution) from 32 rainforest plots in the Australian wet tropics.

\begin{tabular}{llllll}
\hline $\begin{array}{l}\text { Seasonality } \\
\text { variable }\end{array}$ & $\begin{array}{l}\text { Mean (peak) } \\
\text { month }\end{array}$ & Mean & Max & Min & SD \\
\hline Total litterfall & Dec & 0.28 & 0.51 & 0.14 & 0.10 \\
Leaf litterfall & Nov & 0.25 & 0.48 & 0.03 & 0.13 \\
Leaf decomposability & Jan & 0.13 & 0.25 & 0.03 & 0.06 \\
\hline
\end{tabular}

\section{Results}

\subsection{Seasonal litterfall dynamics}

Peak litterfall times in the Australian rainforest region were all between October and April, with the largest peaks occurring in the early wet season, i.e. November-January (Fig. 1a for regional mean and Supplement Table S1 and Fig. S1 for individual plots). Other peaks also occurred in the dry season for some plots (July-October), and in some cases bimodal peaks occurred around December and then February-March (Supplement Fig. S1). Regardless, the regional mean (peak date) for total litterfall was in December, and for leaf litterfall in November (Table 1 and Supplement Table S1).

Total litterfall seasonality index varied from 0.14 (Carbine Uplands $100 \mathrm{~m}$ elevation, semi-deciduous complex mesophyll vine forest) to 0.51 (Spec Uplands $1000 \mathrm{~m}$ elevation, evergreen Acacia closed forest) (Table 1 and Supplement Table $\mathrm{S} 1$ ). Generally higher $\mathrm{SL}_{\text {tot }}$ occurred in the evergreen and quasi-evergreen plots, compared to the semi-evergreen plots (Fig. 2a, mean evergreen $=0.30$; quasi-evergreen $=0.26$; semi-deciduous $=0.14$; ANOVA, $F=12.91, \mathrm{~d} f=31$; LSD post hoc: $P<0.003$ for both comparisons). Leaf litterfall seasonality varied from 0.03 (Atherton Uplands $200 \mathrm{~m}$, quasi-evergreen complex mesophyll vine forest) to 0.48 (Carbine Uplands, evergreen $600 \mathrm{~m}$ notophyll vine forest) (Supplement Table S1). Despite higher mean seasonality in the evergreen group (Fig. $2 b$, mean evergreen $=0.36$; quasi evergreen $=0.24$; semi-deciduous $=0.24$ ), there were no significant differences between groups for $\mathrm{SL}_{\text {leaf }}$, ANOVA, $F=2.831, P=0.52)$. Deciduousness was explained best by MAT (Pearson correlation, 0.731), MAR (0.517) and MAP $(-0.419)(P<0.05)$.

\subsection{Drivers of litterfall seasonality}

Total litterfall seasonality was most strongly correlated with deciduousness (negative), soil $\mathrm{N}$ (positive correlation), the proportion of early secondary species and MAT (negative correlations $)(P<0.05$, Table 2$)$. Our best model explaining $\mathrm{SL}_{\text {tot }}$ contained deciduousness (higher seasonality with less deciduousness, $P<0.0001$ ), soil $\mathrm{N}$ : $\mathrm{P}$ (higher seasonality with higher $\mathrm{N}: \mathrm{P}, P=0.0003)$ and the proportion of early secondary species $(P=0.047$, lower seasonality with more early secondary species) (Fig. 3a, model $r^{2}=0.63$, (a)

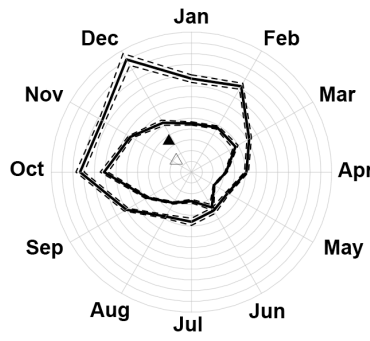

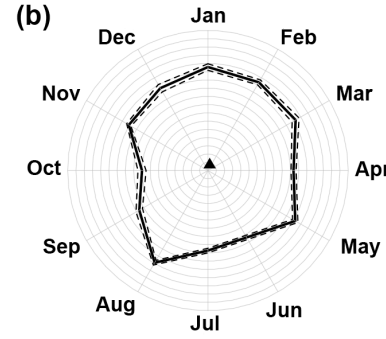

Figure 1. The mean monthly distribution of leaf (inside solid line) and total (outside) litterfall ( $\pm 95 \%$ CI dotted lines) (a) and leaf litter decomposability (b) from 32 plots in Australian wet tropical rainforest. The centroid (mean date) of total litterfall and leaf decomposability is shown by the filled triangle (total and decomposability) and open triangle (leaf). Scales are (a) $0-13 \mathrm{t} \mathrm{ha}^{-1} \mathrm{yr}^{-1}$ and (b) $0-1.7 \mathrm{yr}^{-1}$.

$P<0.0001$, Table 3). As deciduousness and MAT were significantly cross-correlated (Table 2), we produced another model excluding deciduousness from the best-subset analysis. The best model without deciduousness explained $\mathrm{SL}_{\text {tot }}$ with MAT, the proportion of early secondary species and soil N : P (Fig. 3b, model $r^{2}=0.54, P=0.0001$, Table 3). For $\mathrm{SL}_{\text {leaf }}$ the strongest correlations were with plant species richness (positive), deciduousness, MAT, soil $\mathrm{Ca}$ and rainfall seasonality (negative) (Table $2, P<0.05$ ). Our best model explaining SL $\mathrm{SLaf}_{\text {lea }}$ included MAT $(P=0.005)$ and the proportion of early secondary species $(P=0.008)$, with rainfall seasonality explaining the residual variance $(P=0.06)$ (Fig. 3c).

\subsection{Seasonality of leaf decomposability and litter quality}

Leaf litter decomposability was generally more even throughout the year than litterfall $\left(\mathrm{SL}_{\mathrm{decomp}}\right.$ regional mean $=0.13$, Table 1), although some locations showed higher seasonality, with the regional seasonality index ranging from 0.03 (Spec Uplands $1000 \mathrm{~m}$, evergreen Acacia closed forest) to 0.25 (Spec Uplands, $350 \mathrm{~m}$, semideciduous notophyll vine forest) (Fig. 1b, Table 1 and Supplement Table S1). Higher $\mathrm{SL}_{\text {decomp }}$ was present in the semi-deciduous plots $($ mean $=0.16)$ compared to the quasi-evergreen (mean $=0.09$ ) (Fig. 2c, ANOVA, $F=5.35$, $P=0.01$; post hoc test $P=0.002$ ). There were no differences between the evergreen and quasi-evergreen $\mathrm{SL}_{\text {decomp }}$ means, nor between those of semi-deciduous and evergreen (Fig. 2c, $P=0.45$ and 0.43 , respectively).

Regional mean litter decomposability was significantly higher in the wet season (mean date in January, mean $\left.=1.20 \mathrm{y}^{-1}\right)$ than the dry season $\left(\right.$ mean $\left.=1.08 \mathrm{yr}^{-1}\right)$ (effect of season $P<0.001$, Table 4); however a large peak in decomposability also occurred in the dry season around August (Fig. 1b). 
Table 2. Correlations of climate, soil, litter dynamics and community composition with seasonality from the Australian rainforest region $(n=32$ plots $)$.

\begin{tabular}{|c|c|c|c|c|c|c|}
\hline & Variable & $\begin{array}{l}\text { SL } \\
\text { (total) }\end{array}$ & $\begin{array}{l}\text { SL } \\
\text { (leaf) }\end{array}$ & $\begin{array}{l}\text { SL } \\
\text { decomp. }\end{array}$ & $\begin{array}{l}\text { Decomp. } \\
\text { (seasonal diff) } \\
\frac{\mu_{\mathrm{dry}}-\mu_{\mathrm{wet}}}{\mu_{\mathrm{wd}}}(\%)\end{array}$ & $\begin{array}{l}\text { Deciduous- } \\
\text { ness }^{\text {a }}\end{array}$ \\
\hline Climate & MAP & -0.042 & -0.05 & -0.294 & 0.018 & $-0.419^{*}$ \\
\hline & $\begin{array}{l}\text { Rainfall seasonality } \\
\text { Dry season moisture } \\
\text { MAR } \\
\text { MAT }\end{array}$ & $\begin{array}{l}0.188 \\
-0.233 \\
-0.026 \\
-0.449^{* *}\end{array}$ & $\begin{array}{c}-0.334 \\
0.051 \\
0.045 \\
-0.405^{*}\end{array}$ & $\begin{array}{c}0.074 \\
-0.319^{*} \\
0.354^{*} \\
0.344\end{array}$ & $\begin{array}{l}-0.217 \\
0.449^{* *} \\
-0.043 \\
-0.345\end{array}$ & $\begin{array}{l}0.331 \\
0.105 \\
0.517^{* *} \\
0.731^{* * *}\end{array}$ \\
\hline Soil & $\begin{array}{l}\text { Soil Ca } \\
\text { Soil Na } \\
\text { Soil N } \\
\text { Soil P } \\
\text { Soil N : P } \\
\text { Soil TOC }\end{array}$ & $\begin{array}{c}-0.197 \\
-0.136 \\
0.517^{* *} \\
0.058 \\
0.251 \\
0.204\end{array}$ & $\begin{array}{c}-0.421^{*} \\
0.073 \\
-0.142 \\
0.126 \\
-0.281 \\
0.035\end{array}$ & $\begin{array}{l}-0.131 \\
-0.085 \\
-0.531^{* *} \\
-0.391^{*} \\
-0.224 \\
-0.002\end{array}$ & $\begin{array}{r}0.101 \\
0.328 \\
0.308 \\
0.044 \\
-0.105 \\
0.094\end{array}$ & $\begin{array}{r}0.215 \\
0.061 \\
-0.066 \\
-0.112 \\
0.130 \\
0.104\end{array}$ \\
\hline Litter & $\begin{array}{l}\text { Litterfall rate } \\
\text { Leaf decomposability }\end{array}$ & $\begin{array}{l}-0.095 \\
-0.329\end{array}$ & $\begin{array}{l}-0.286 \\
-0.192\end{array}$ & $\begin{array}{r}0.104 \\
-0.292\end{array}$ & $\begin{array}{l}-0.130 \\
-0.031\end{array}$ & $\begin{array}{r}0.079 \\
-0.085\end{array}$ \\
\hline Community & $\begin{array}{l}\text { Plant species richness } \\
\text { Plant density } \\
\text { Early secondary species } \\
\text { Deciduousness }\end{array}$ & $\begin{array}{l}0.097 \\
0.12 \\
-0.387^{*} \\
-0.602^{* * *}\end{array}$ & $\begin{array}{c}0.449^{*} \\
0.337 \\
-0.312 \\
-0.384^{*}\end{array}$ & $\begin{array}{l}0.045 \\
0.187 \\
0.055 \\
0.309\end{array}$ & $\begin{array}{c}0.302 \\
0.275 \\
-0.030 \\
-0.398^{*}\end{array}$ & $\begin{array}{c}-0.193 \\
-0.158 \\
0.245 \\
-\end{array}$ \\
\hline
\end{tabular}

${ }^{a}$ Deciduousness contained three levels $-1=$ evergreen; $2=$ quasi-evergreen; $3=$ semi-deciduous (see text for definitions). ${ }^{*}: p<0.05 ; * *$ : $p<0.01{ }^{* * *}: p<0.001$.

Table 3. Best-subset linear model results explaining the seasonality in total litterfall ( $\mathrm{SL}_{\text {total }}$, two models), leaf litterfall ( $\mathrm{SL}_{\mathrm{leaf}}$ ), leaf decomposability $\left(\mathrm{SL}_{\mathrm{decomp}}\right)$ and the difference between dry season and wet season decomposability, from plots in Australian tropical rainforest. $n=32$ except for models that included early secondary species, where $n=30$ due to missing data (Table S1).

\begin{tabular}{|c|c|c|c|c|c|c|}
\hline & Variable & Est. & $p$ (var.) & $r^{2}$ & $n$ & Model $p$ \\
\hline \multirow[t]{4}{*}{$\mathrm{SL}_{\text {total }}(1)$} & (Intercept) & 0.406 & $<0.0001$ & 0.63 & 30 & $<0.0001$ \\
\hline & Soil N : P & 0.004 & 0.0003 & & & \\
\hline & Early secondary species & -0.002 & 0.047 & & & \\
\hline & Deciduousness & -0.071 & $<0.0001$ & & & \\
\hline \multirow[t]{4}{*}{$\mathrm{SL}_{\text {total }}(2)$} & (Intercept) & 0.72 & $<0.0001$ & 0.54 & 30 & 0.0001 \\
\hline & MAT & -0.02 & 0.001 & & & \\
\hline & Early secondary species & -0.003 & 0.005 & & & \\
\hline & Soil $\mathrm{N}$ : $\mathrm{P}$ & 0.004 & 0.001 & & & \\
\hline \multirow[t]{4}{*}{$\mathrm{SL}_{\text {leaf }}$} & (Intercept) & 0.501 & 0.009 & 0.39 & 30 & 0.004 \\
\hline & MAT & -0.024 & 0.005 & & & \\
\hline & Early secondary species & -0.002 & 0.008 & & & \\
\hline & Rainfall seasonality & 0.003 & 0.06 & & & \\
\hline \multirow[t]{4}{*}{$\mathrm{SL}_{\text {decomp }}$} & (Intercept) & 0.237 & 0.02 & 0.55 & 32 & $<0.0001$ \\
\hline & MAT & 0.009 & 0.01 & & & \\
\hline & Dry season moisture & -0.003 & 0.004 & & & \\
\hline & Soil N & -0.23 & 0.0001 & & & \\
\hline \multirow{2}{*}{$\begin{array}{l}\text { Decomposability } \\
\frac{\mu_{\mathrm{dry}}-\mu_{\mathrm{wet}}}{\mu_{\mathrm{wd}}}(\%)\end{array}$} & (Intercept) & -56.82 & 0.002 & 0.20 & 32 & 0.010 \\
\hline & Dry season moisture & 0.590 & 0.010 & & & \\
\hline
\end{tabular}


Table 4. Results of two-way repeated measures ANOVA for seasonal concentrations, wet (31 October-1 April) and dry season, of leaf litter chemical components, from sites in Australian tropical rainforests ( $n=32$ plots; number of samples per treatment is shown in parentheses).

\begin{tabular}{llccccc}
\hline Variable & Effect & df & $F$ & Wet mean & Dry mean & $p$ \\
\hline Decomposability & Season & 1 & 58.891 & $1.20 \pm 0.01$ & $1.08 \pm 0.01$ & $<0.001$ \\
& Season*plot & 31 & 1.777 & $(781)$ & $(993)$ & 0.005 \\
$\mathrm{~N}$ & Season & 1 & 5.613 & $1.21 \pm 0.01$ & $1.23 \pm 0.01$ & 0.024 \\
& Season*plot & 31 & 1.450 & $(801)$ & $(1018)$ & 0.053 \\
$\mathrm{P}$ & Season & 1 & 0.398 & $0.03 \pm 0.001$ & $0.03 \pm 0.001$ & 0.533 \\
& Season*plot & 31 & 1.829 & $(809)$ & $(1018)$ & 0.004 \\
$\mathrm{Ca}$ & Season & 1 & 6.901 & $0.97 \pm 0.01$ & $0.91 \pm 0.01$ & 0.013 \\
& Season*plot & 31 & 1.814 & $(801)$ & $(1018)$ & 0.004 \\
$\mathrm{C}$ & Season & 1 & 0.107 & $48.8 \pm 0.05$ & $48.9 \pm 0.05$ & 0.746 \\
& Season*plot & 31 & 1.975 & $(801)$ & $(1018)$ & 0.001 \\
Lignin & Season & 1 & 74.72 & $36.5 \pm 0.14$ & $34.1 \pm 0.12$ & $<0.001$ \\
& Season*plot & 31 & 2.322 & $(801)$ & $(1017)$ & $<0.001$ \\
$\alpha$-Cellulose & Season & 1 & 23.76 & $20.3 \pm 0.07$ & $19.6 \pm 0.06$ & $<0.001$ \\
& Season*plot & 31 & 2.882 & $(800)$ & $(1017)$ & $<0.001$ \\
Phenolics & Season & 1 & 191.3 & $0.44 \pm 0.01$ & $0.63 \pm 0.01$ & $<0.001$ \\
& Season*plot & 31 & 2.680 & $(801)$ & $(1018)$ & $<0.001$ \\
\hline
\end{tabular}

(a)

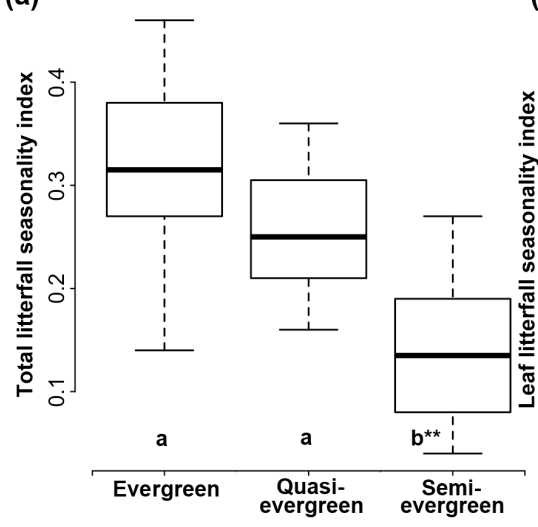

(b)

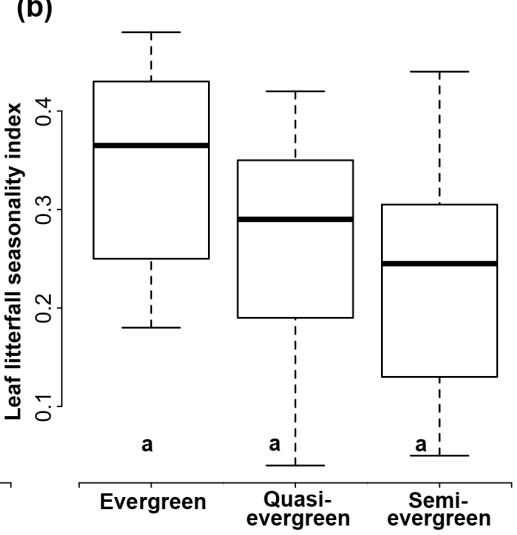

(c)

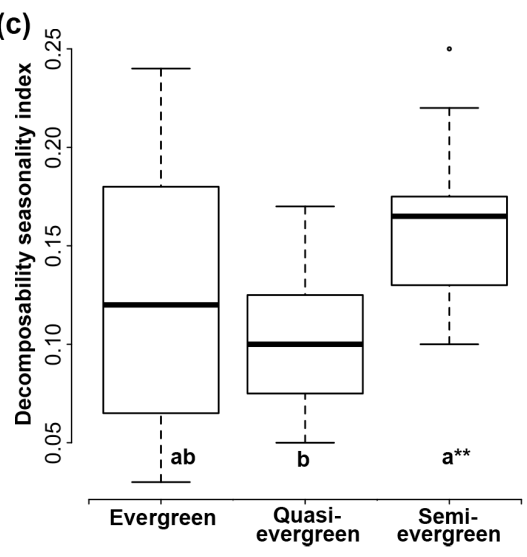

Figure 2. Seasonality by deciduousness based on the classifications in Webb (1968): (a) total litterfall, (b) leaf litterfall and (c) leaf decomposability.

Comparing the level of $\mathrm{SL}_{\text {decomp }}$ between plots showed higher seasonality with higher MAR, and lower $\mathrm{SL}_{\text {decomp }}$ with higher soil $\mathrm{N}$ and $P$ (Pearson correlation $P<0.05$ for all, Table 2). The best model explaining $\mathrm{SL}_{\text {decomp }}$ contained MAT ( $P=0.02$, higher seasonality with higher MAT), dry season moisture $(P=0.004$, lower seasonality with more moisture) and soil $\mathrm{N}(P=0.0001$, lower seasonality with higher soil $\mathrm{N}$ ) (model $r^{2}=0.55, P<0.0001$, Table 3 ).

Mean leaf litter $\mathrm{N}$ and total phenolic concentrations were both higher in the dry season (Table $4, P=0.02$ and $<0.001$, respectively). Higher means in the wet season were present for $\alpha$-cellulose, lignin and Ca $(P<0.01$ for all, Table 4$)$.

Most plots showed higher mean wet season leaf litter decomposability compared to dry season means (Table S1). The extent of the difference between dry season and wet season mean decomposability values correlated best with dry season moisture, suggesting increased seasonal differences (i.e. lower decomposability in the dry season) at plots with higher moisture seasonality (Table 2). Similarly, our best linear model explaining the seasonal differences in leaf decomposability contained only dry season moisture $\left(r^{2}=0.2\right.$, $P=0.010$, Table 4 and Fig. 4).

\section{Discussion}

The seasonality of litterfall shows diverse patterns globally; however in tropical forests, peaks most often occur in the dry season months, potentially as a response to moisture stress (Zhang et al., 2014). Australian tropical forests show a divergent pattern in litterfall timing to most wet tropical locations, with the highest falls in the wettest, warmest months 
(a)
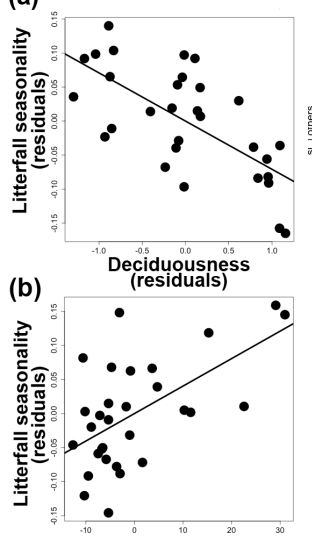

(c) Soil N:P (residuals)
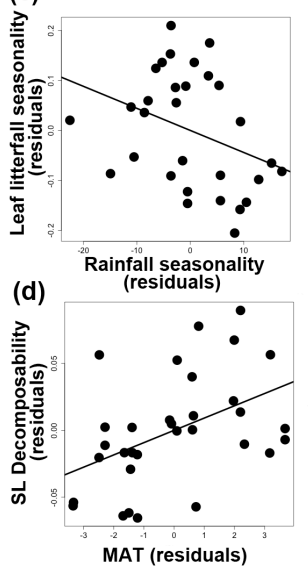

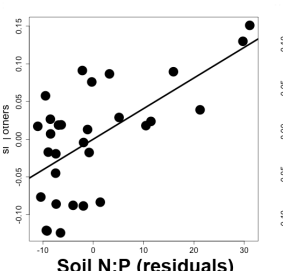

Soil N:P (residuals)
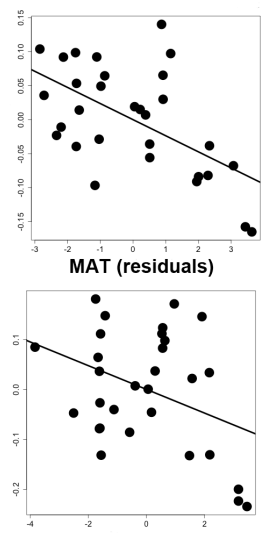

MAT (residuals)

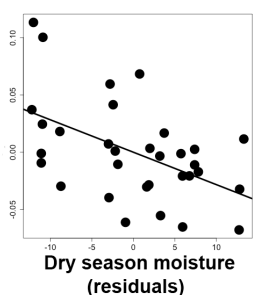

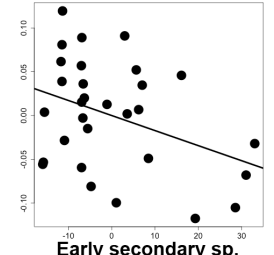

Early secondary sp.
(residuals)
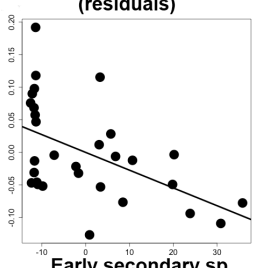

Early secondary sp. (residuals)

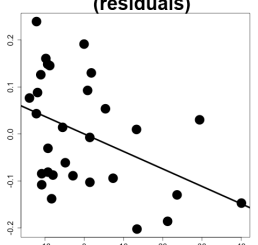

Early secondary sp. (residuals)

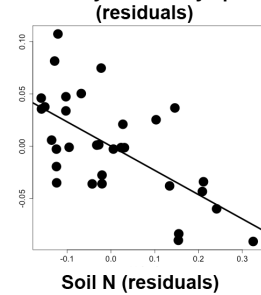

Figure 3. Partial regression plots from linear models explaining litter seasonality in Australian tropical rainforests: (a) total litterfall model 1, (b) total litterfall model 2, (c) leaf litterfall and (d) leaf decomposability.

with the highest annually insolation (Hopkins and Graham, 1989; Herbohn and Congdon, 1993; Stocker et al., 1995; Parsons et al., 2014). Peak litterfall from the end of the dry season and into the wet occurs in other locations globally (Edwards, 1977; Herbohn and Congdon, 1993) but is a less common pattern (Zhang et al., 2014). Our results also support that notable intra-annual changes in litter chemical composition, with direct impacts on decomposition and ecosystem processes, occur in seasonally wet tropical forests.

In a comprehensive review of litterfall seasonality in a tropical region, and using the same circular seasonality calculations as us, Chave et al. (2010) showed lower seasonality for South American rainforests (Australian mean of 0.28 compared to 0.17 in South America). Higher rainfall seasonality in Australian rainforests, compared to much of the new world, may explain this difference (Chave et al., 2010; Parsons, 2011). Increased rainfall seasonality also led to higher litterfall seasonality in the new-world rainforests (Chave et al., 2010), which is the general trend for tropical rainforests globally (Zhang et al., 2014). However, in our region, in-

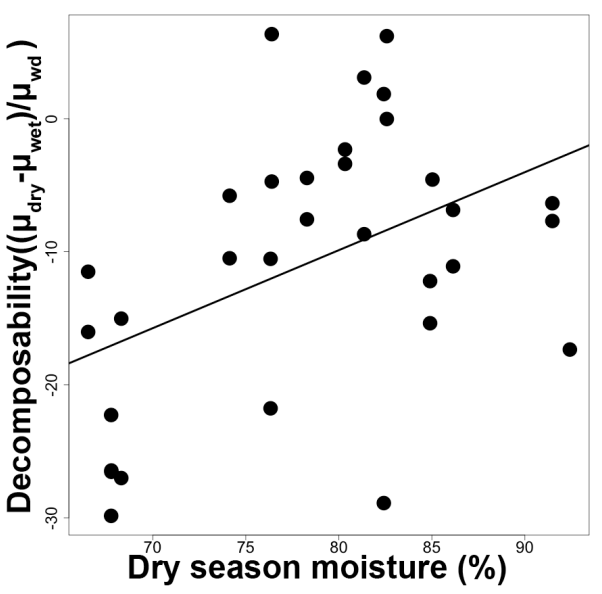

Figure 4. Linear model representing the difference between dry season and wet season leaf decomposability for 32 plots in Australian tropical rainforest. Negative values for the seasonal difference show lower decomposability in the dry season for the plots ( $y$ axis: dry season minus wet season value, as percentage of the plot mean).

creased litterfall seasonality was best explained by a combination of cooler temperatures (i.e. upland rainforests), lower abundances of early successional species, and phosphorus limitation (i.e. higher soil $\mathrm{N}: \mathrm{P}$ ), with rainfall secondary to these factors. Likewise, deciduousness was a primary driver of this variance, as increasingly deciduous sites had more consistent monthly litterfall inputs. Moisture contributed to the pattern as a driver of deciduousness and as a correlate with $\mathrm{N}$ : $\mathrm{P}$; however higher rainfall seasonality generally led to lower litterfall seasonality ( $\mathrm{SL}_{\text {leaf }}$ model Fig. 3c), which is contrary to the global trend (Chave et al., 2010; Zhang et al., 2014).

In most tropical forests, the timing of litterfall may be driven by water stress, especially when peaks occur in the dry seasons (Wieder and Wright, 1995). Studies in the tropical north Queensland region, however, have shown that the bulk of litterfall is not primarily triggered by annual drought (in the winter months), because increased litterfall co-occurs with periods of high water availability (at the start of the wet season, and coinciding with new leaf flushes) (Hopkins and Graham, 1989). Short-term moisture stress in the warmer summer months (e.g. short periods of no rain and higher insolation) is, however, likely to contribute to this pattern, for instance bimodal litterfall timing (Hopkins and Graham, 1989). We saw that, within our region, both this wet season pattern shown by previous authors and earlier falls in the dry season do co-occur, especially in locations with a higher prevalence of deciduous species.

The level of deciduousness of our plots explained seasonality better than any other variable, with greater deciduousness leading to more consistent monthly inputs. Increased deciduousness in Australian rainforests is a function of higher temperatures, lower rainfall/higher rainfall seasonality, and 
lower soil fertility (Webb, 1968), as was generally supported in our study sites. This supports our pattern of generally lower litterfall seasonality with lower moisture. That is, we found lower seasonality in the more deciduous plots that are characteristically drier (Table 2; Webb, 1968). Also, in our region, the effects of temperature and soil fertility and their impacts on deciduousness were generally more important than moisture in explaining variability in seasonality. However, the weak but significant relationship of higher soil $\mathrm{N}: \mathrm{P}$ with increased rainfall seasonality may have reduced the influence of moisture in our models. Regardless, evergreen forests, which were largely in the cooler uplands, had higher litterfall seasonality, while still covering a range of rainfall seasonality patterns. Thus, the level of deciduousness as a driver of litterfall seasonality explains this contrasting trend.

The trend of more consistent monthly litterfall with increased deciduousness is explained by the season of leaf shed being inconsistent across deciduous/semi-deciduous rainforest species (Hyland et al., 2002). For instance, large litterfalls, e.g. complete leaf shedding, can occur from mid-late in the dry season and continue throughout the wet, depending on the species phenology (Hyland et al., 2002), as well as climatic conditions of that year (Backer et al., 2003). Our study suggests that this is spatially heterogeneous, even within a relatively small bioregion. Moreover, we found that a higher abundance of deciduous/semi-deciduous species brings a greater mix of litterfall characteristics, e.g. some species shed at the start of the wet season (like the general trend in our region), while other co-occurring deciduous/semi-deciduous species shed large amounts of litter in drier times (Supplement Fig. S1; Hyland et al., 2002; S. A. Parsons, personal observations 2009). In evergreen forests, the seasonal litterfall response appears more consistent across species. The blend of litterfall patterns in more deciduous/semi-deciduous rainforest plots, leading to more consistent litter inputs annually, is an important consideration for those modelling seasonality in forest processes and biogeochemical cycles (De Weirdt et al., 2012).

Our models suggest that the seasonality of litterfall increased with greater $P$ limitation. As is characteristic of tropical rainforests, our sites had relatively high soil $\mathrm{N}$ but very low soil $P$ (Parsons et al., 2014). Thus, when $\mathrm{N}$ is higher in soils, the N:P imbalance leads to limitation of $P$ to plants and microbes (Sardans et al., 2012). Although we found no direct relationship between deciduousness and soil nutrients (including $\mathrm{N}: \mathrm{P}$, Table 2), it is likely that a combination of $P$ limitation (i.e. higher soil $\mathrm{N}: \mathrm{P}$ ) and moisture limitation (cooccurring with higher $\mathrm{N}: \mathrm{P}$ ) works to increase litterfall seasonality in our region as a function of deciduousness. Litterfall quantities can also be constrained by nutrient availability, particularly $P$, in humid tropical forests (Silver, 1994; Tanner et al., 1998). The causes of lower rates and more seasonal litter inputs when nutrient availability is low are a combination of slower growth, longer-lived tissues and less tissue produc- tion (e.g. less material shed) (Vitousek, 1984, Silver, 1994), and, as our results suggest, the environmental/physiological triggers of litterfall being more consistent across species. Importantly, the triggers of litterfall may be inherent physiological traits of the species (e.g. fully deciduous species that drop leaves due to moisture stress/new growth at one time of the year), or driven by environmental factors that may vary in their timing (e.g. semi-deciduous species that lose leaves as a response to new growth driven by the onset of rain or increased solar radiation). The latter of these drivers may cause litter to fall more evenly throughout the year in many tropical forests, due to more consistent growth/productivity. This mix of characteristics leads to varying litterfall patterns both between and within rainforest sites. As we showed here, this can be traced back to an understanding of the characteristics/classification of the vegetation, soil fertility and climate.

Notably, plant species composition and disturbance histories were important drivers of litterfall seasonality here. Secondary rainforests generally have altered litterfall, faster growth and leaf turnover rates (Laurance et al., 2002; XulucTolosa et al., 2003), and can have more decomposable litter (Vasconcelos and Laurance, 2005), although not always (Parsons and Congdon, 2008), compared to primary rainforest. Generally, however, increased resource use efficiency in rainforest secondary species may explain the more consistent litter inputs (Kuijk and Anten, 2009). This is probably related to more consistent growth in harsher times at sites with higher proliferation of species favoured by disturbance and species characteristic of regrowth (Kuijk and Anten, 2009; Poorter and Bongers, 2006).

Our study suggests that moisture effects, as well as the coupled changes in solar radiation, were generally more important in determining seasonal shifts in litter chemical compositions and quality than litterfall quantities, e.g. for decomposition. Townsend et al. (2007) found higher litter $P$ in the dry season in Costa Rican sites, lowering $\mathrm{N}: \mathrm{P}$ in litter inputs. In contrast, we did not find a significant seasonal effect for litter $P$. Instead, we found an effect for $\mathrm{N}$, being slightly lower in the wet season. The reasons for this are unclear; however they could be due to more N-rich green litter falling in the dry season (e.g. from wind inputs). Similarly, the peak in litter decomposability seen around August may have been partially due to increased inputs of green leafy material brought down by the sometimes stronger trade winds around this time (Australian Bureau of Meteorology, and Wang, 2001). That is, green leaves generally have higher nutrient contents due to reabsorption prior to senescence (Herbohn, 1993; Vera et al., 1999), likely increasing decomposability (Parsons et al., 2011, 2012). However, the true cause of this pattern is somewhat unclear, because the peak in decomposability did not co-occur with a spike in leaf litterfall, and winds can also be elevated in the wetter months bringing down similarly large amounts of more decomposable green leaves. 
Moreover, our data show that decreased litter decomposability in the dry season is driven mostly by decreases in total phenolic contents. Phenolics are strong limiters of litter decay in our region (Parsons et al., 2012), similar to other tropical rainforest sites (Hättenschwiler et al., 2011). We showed here that, in the north Queensland region, these components of litter quality are more important in affecting seasonal changes in litter decomposability than other litter variables (i.e. higher lignin and lower nutrients $\mathrm{Ca}$ and $\mathrm{N}$ in dry season litter). Phenolics are known to increase in concentrations in forested sites prone to higher solar radiation and nutrient stress (Close and McArthur, 2002; Read et al., 2009), a dynamic that occurs in the north Queensland region (Parsons, 2011; Parsons et al., 2014). These changes were exacerbated by climate (i.e. moisture availability in the dry season and higher annual temperatures), while also being mediated by higher soil $\mathrm{N}$ (Fig. 3d). Of these, however, moisture was more important in explaining increased litter recalcitrance in the dry season (Fig. 4) compared to the overall difference. What is notable about the seasonal effect for phenolics and decomposability in this work is that changes in these factors occurred over the short term. Our coarse quantification of total phenolics here does not allude to the true chemical causes of this phenomenon. In a temperate ecosystem, Riipi et al. (2002) found that seasonal changes in plant secondary metabolites differed greatly depending on the compound in question. However, it is unclear how short-term changes in green, photosynthesising leaves, carried on into mixed, but mostly senesced, litter of varying ages. This warrants further enquiry, because short-term changes moisture seasonality and increased solar radiation, along with higher overall temperatures, under future climates (Suppiah et al., 2007) may have an impact on litter quality in this way, thus altering decomposition and biogeochemical cycles.

\section{The Supplement related to this article is available online at doi:10.5194/bg-11-5047-2014-supplement.}

Author contributions. S. A. Parsons, V. Valdez-Ramirez, R. A. Congdon and S. E. Williams designed the study; S. A. Parsons and V. Valdez-Ramirez performed fieldwork and collected and sorted the litter samples; and S. A. Parsons performed laboratory, chemical and statistical/data analyses and wrote the manuscript.

Acknowledgements. We thank Ivan Lawler, Yvette Williams, Luke Shoo, Collin Storlie and the members of the Centre for Tropical Biodiversity and Climate Change for support throughout this study. The Skyrail Rainforest Foundation, the Queensland government Smart-State funding programme, the Marine and Tropical Sciences Research Facility, and the James Cook University School of Marine and Tropical Biology funded this work. The Queensland Parks and Wildlife Service and traditional owners are thanked for access to the study sites.

Edited by: Y. Kuzyakov

\section{References}

Aragão, L. E. O. C., Malhi, Y., Metcalfe, D. B., Silva-Espejo, J. E., Jiménez, E., Navarrete, D., Almeida, S., Costa, A. C. L., Salinas, N., Phillips, O. L., Anderson, L. O., Alvarez, E., Baker, T. R., Goncalvez, P. H., Huamán-Ovalle, J., Mamani-Solórzano, M., Meir, P., Monteagudo, A., Patiño, S., Peñuela, M. C., Prieto, A., Quesada, C. A., Rozas-Dávila, A., Rudas, A., Silva Jr., J. A., and Vásquez, R.: Above- and below-ground net primary productivity across ten Amazonian forests on contrasting soils, Biogeosciences, 6, 2759-2778, doi:10.5194/bg-6-2759-2009, 2009.

Australian Bureau of Meteorology, and Wang, Q. J.: Climatic atlas of Australia: evapotranspiration, Bureau of Meteorology, Melbourne, 2001.

Baker, T. R., Swaine, M. D., and Burslem, D. F.: Variation in tropical forest growth rates: combined effects of functional group composition and resource availability. Perspectives in Plant Ecology, Evol. System., 6, 21-36, 2003.

Bousquet, P., Peylin, P., Ciais, P., Le Quéré, C., Friedlingstein, P., and Tans, P. P.: Regional changes in carbon dioxide fluxes of land and oceans since 1980, Science, 290, 1342-1347, 2000.

Chave, J., Navarrete, D., Almeida, S., Álvarez, E., Aragão, L. E. O. C., Bonal, D., Châtelet, P., Silva-Espejo, J. E., Goret, J.-Y., von Hildebrand, P., Jiménez, E., Patiño, S., Peñuela, M. C., Phillips, O. L., Stevenson, P., and Malhi, Y.: Regional and seasonal patterns of litterfall in tropical South America, Biogeosciences, 7, 43-55, doi:10.5194/bg-7-43-2010, 2010.

Clark, D. A., Brown, S., Kicklighter, D. W., Chambers, J. Q., Thomlinson, J. R., and Ni, J.: Measuring net primary production in forests: concepts and field methods, Ecol. Appl., 11, 356-370, 2001a.

Clark, D.A., Brown, S., Kicklighter, D.W., Chambers, J.Q., Thomlinson, J.R., Ni, J., and Holland, E.A.: Net primary production in tropical forests: an evaluation and synthesis of existing field data, Ecol. Appl., 11, 371-384, 2001 b.

Close, D. C. and McArthur, C.: Rethinking the role of many plant phenolics- protection from photodamage not herbivores?, Oikos, 99, 166-172, 2002.

Cornwell, W. K., Cornelissen, J. H. C., Amatangelo, K., Dorrepaal, E., Eviner, V. T., Godoy, O., Hobbie, S. E., Hoorens, B., Kurokawa, H., Pérez-Harguindeguy, N., Quested, H. M., Santiago, L. S., Wardle, D. A., Wright, I. J., Aerts, R., Allison, S. D., van Bodegom, P., Brovkin, V., Chatain, A., Callaghan, T. V., Díaz, S., Garnier, E., Gurvich, D. E., Kazakou, E., Klein, J. A., Read, J., Reich, P. B., Soudzilovskaia, N. A., Vaieretti, M. V., and Westoby, M.: Plant species traits are the predominant control on litter decomposition rates within biomes worldwide, Ecol Lett, 11, 1065-1071, 2008.

De Weirdt, M., Verbeeck, H., Maignan, F., Peylin, P., Poulter, B., Bonal, D., Ciais, P., and Steppe, K.: Seasonal leaf dynamics for tropical evergreen forests in a process-based global ecosystem model, Geosci. Model Dev., 5, 1091-1108, doi:10.5194/gmd-51091-2012, 2012.

Edwards, P. J.: Studies of mineral cycling in a montane rainforest in New Guinea, II. The production and disappearance of litter, J. Ecol., 65, 971-992, 1977.

Fierer, N., Craine, J. M., McLauchlan, K., and Schimel, J. P.: Litter quality and the temperature sensitivity of decomposition, Ecology, 86, 320-326, 2005. 
Hättenschwiler, S., Coq, S., Barantal, S., and Handa, I.T.: Leaf traits and decomposition in tropical rainforests: revisiting some commonly held views and towards a new hypothesis, New Phytologist, 189, 950-965, 2011.

Herbohn, J. L.: The role of litterfall in nutrient cycling at disturbed and undisturbed sites in tropical rainforest in North Queensland, $\mathrm{PhD}$ thesis, James Cook University, 1993.

Herbohn, J. L. and Congdon, R. A.: Ecosystem dynamics at disturbed and undisturbed sites in north Queensland wet tropical rain forest: II. Litterfall, J. Trop. Ecol., 9, 365-379, 1993.

Hopkins, M. S. and Graham, A. W.: Community phenological patterns of a lowland tropical rainforest in north-eastern Australia, Austral. J. Ecol., 14, 399-413, 1989.

Hyland, B. P. M., Whiffen, T., Christophel, D. C., Gray, B., and Elick, R. W.: Australian Tropical Rainforest Plants - Trees, Shrubs and Vines, CSIRO, Melbourne, 2002.

Jammalamadaka, S. R. and Sengupta, A.: Topics in circular statistics, World Scientific Pub Co Inc, New York, 2001.

Kuijk, M. and Anten, N. P. R.: Whole-canopy nitrogen-use efficiency of pioneer species in early secondary forest succession in Vietnam, Ecol. Res., 24, 811-820, 2009.

Laurance, W. F., Lovejoy, T. E., Vasconcelos, H. L., Bruna, E. M., Didham, R. K., Stouffer, P. C., Gascon, C., Bierregaard, R. O., Laurance, S. G., and Sampaio, E.: Ecosystem decay of Amazonian forest fragments: a 22-year investigation, Conserv. Biol., 16, 605-618, 2002.

Parsons S. A.: Decomposition, nutrient cycling and climate change in Australian tropical rainforests, $\mathrm{PhD}$ thesis, James Cook University, 2011.

Parsons, S. A. and Congdon, R. A.: Plant litter decomposition and nutrient cycling in north Queensland tropical rainforest communities of differing successional status, J. Trop. Ecol., 24, 317327, 2008.

Parsons, S. A., Lawler, I. R., Congdon, R. A., and Williams, S. E.: Rainforest litter quality and chemical controls on leaf decomposition with near infrared spectrometry, J. Plant Nutrit. Soil Sci., 174, 710-720, 2011

Parsons, S. A., Congdon, R. A., Storlie, C. J., Shoo, L. P., and Williams, S. E.: Regional patterns and controls on leaf decomposition in Australian tropical rainforests, Austral. Ecol., 37, 845854, 2012.

Parsons, S. A., Congdon, R. A., Shoo, L. P., Valdez-Ramirez, V., and Williams, S. E.: Spatial variability in litterfall, litter standing crop and litter quality in a tropical rainforest region, Biotropica, 46, 378-386, 2014.

Poorter, L. and Bongers, F.: Leaf traits are good predictors of plant performance across 53 rain forest species, Ecology, 87, 17331743, 2006.

Read, J., Sanson, G. D., Caldwell, E., Clissold, F. J., Chatain, A., Peeters, P., Lamont, B. B., De Garine-Wichatitsky, M., Jaffré, T., and Kerr, S.: Correlations between leaf toughness and phenolics among species in contrasting environments of Australia and New Caledonia, Ann. Botany, 103, 757-67, 2009.

Restrepo-Coupe, N., da Rocha, H. R., Hutyra, L. R., da Araujo, A. C., Borma, L. S., Christoffersen, B., Cabral, O. M., de Camargo, P. B., Cardoso, F. L., da Costa, A. C. L., Fitzjarrald, D. R., Goulden, M. L., Kruijt, B., Maia, J. M., Malhi, Y. S., Manzi, A. O., Miller, S. D., Nobre, A. D., von Randow, C., Sá, L. D. A., Sakai, R. K., Tota, J., Wofsy, S. C., Zanchi, F. B., and Saleska,
S. R.: What drives the seasonality of photosynthesis across the Amazon basin?, A cross-site analysis of eddy flux tower measurements from the Brasil flux network, Agr. Forest Meteorol., 182/183, 128-144, 2013.

Riipi, M., Ossipov, V., Lempa, K., Haukioja, E., Koricheva, J., Ossipova, S., and Pihlaja, K.: Seasonal changes in birch leaf chemistry: are there trade-offs between leaf growth and accumulation of phenolics?, Oecologia, 130, 380-390, 2002.

Sardans, J., Rivas-Ubach, A., and Peñuelas, J.: The C:N : P stoichiometry of organisms and ecosystems in a changing world: A review and perspectives, Perspectives in Plant Ecology, Evol. System., 14, 33-47, 2012.

Silver, W. L.: Is nutrient availability related to plant nutrient use in humid tropical forests?, Oecologia, 98, 336-343, 1994.

Stocker, G. C., Thompson, W. A., Irvine, A. K., Fitzsimon, J. D., and Thomas, P. R.: Annual patterns of litterfall in a lowland and tableland rainforest in tropical Australia, Biotropica, 27, 412420, 1995.

Suppiah, R., Macadam, I., and Whetton, P. H.: Climate change projections for the tropical rainforest region of north Queensland, CSIRO Marine and Atmospheric Research and Reef and Rainforest Research Centre Limited, Cairns, 2007.

Tanner, E. V. J., Vitousek, P. M., and Cuevas, E.: Experimental investigation of nutrient limitation of forest growth on wet tropical mountains, Ecology, 79, 10-22, 1998.

Townsend, A. R., Cleveland, C. C., Asner, G. P., and Bustamante, M. M. C.: Controls over foliar $\mathrm{N}$ : $\mathrm{P}$ ratios in tropical rain forests, Ecology, 88, 107-18, 2007.

Townsend, A. R., Asner, G. P., and Cleveland, C. C.: The biogeochemical heterogeneity of tropical forests, Trend. Ecol. Evolut., 23, 424-31, 2008.

Vasconcelos, H. and Laurance, W.: Influence of habitat, litter type, and soil invertebrates on leaf-litter decomposition in a fragmented Amazonian landscape, Oecologia, 144, 456-462, 2005.

Vera, M., Cavelier, J., and Santamaria, J.: Tree leaf nitrogen and phosphorus reabsorption in a montane forest of the central Andes, Colombia, Revista de Biologia Tropical, 47, 33-43, 1999.

Vitousek, P. M.: Litterfall nutrient cycling and nutrient limitation in tropical forests, Ecology, 65, 285-298, 1984.

Webb, L. J.: Environmental Relationships of the Structural Types of Australian Rain Forest Vegetation, Ecology, 49, 296-311, 1968.

Wieder, R. K. and Lang, G. E.: A critique of the analytical methods used in examining decomposition data obtained from litter bags, Ecology, 63, 1636-1642, 1982.

Wieder, R. K. and Wright, S.J.: Tropical forest litter dynamics and dry season irrigation on Barro Colorado Island, Panama, Ecology, 76, 1971-1979, 1995.

Xuluc-Tolosa, F. J., Vester, H. F. M., Ramirez-Marcial, N., Castellanos-Albores, J., and Lawrence, D.: Leaf litter decomposition of tree species in three successional phases of tropical dry secondary forest in Campeche, Mexico, Forest Ecol. Manage., 174, 401-412, 2003.

Zhang, H., Yuan, W., Dong, W., and Liu, S.: Seasonal patterns of litterfall in forest ecosystem worldwide, Ecological Complexity, doi:10.1016/j.ecocom.2014.01.003, 2014.

Zimmerman, J. K., Wright, S. J., Calderón, O., Pagan, M. A., and Paton, S.: Flowering and fruiting phenologies of seasonal and aseasonal neotropical forests: the role of annual changes in irradiance, J. Trop. Ecol., 23, 231-251, 2007. 